4. Бугайчук К.Л., Шорохова Г.М. Забезпечення кібербезпеки як умова протидії терористичній діяльності: нормативно-правові аспекти. Протидія терористичній діяльноcmi : міжнародний досвід і його актуальність для України : матеріали II Міжнародної науково-практичної конференції (15 грудня 2017 р.). Київ : Національна академія прокуратури України, 2018. С. 135-138.

5. Діордіца I.B. Поняття та зміст національної системи кібербезпеки. URL: http:/goal-int.org/ponyattyata-zmist-nacionalnoi-sistemi-kiberbezpeki/ (дата звернення: 11.11.2019).

6. Ліпкан В.А. Поняття системи забезпечення національної безпеки України. Право і Безпека. 2003. Т. 2. № 4. С. 57-60.

7. Політологія : навчальний посібник / М.П. Гетьманчук, В.К. Грищук, Я.Б. Турчин та ін. ; за заг. ред. М.П. Гетьманчука. Київ : Знання, 2010. 415 с.

8. Скулиш Є.Д. Інформаційна безпека: нові виклики українському суспільству. Інформація і право. № 2 (5). 2012. С. 175-183.

9. Ткаченко В.І., Смірнов Є.Б., Астахов О.О. Шляхи формування системи забезпечення національної безпеки. Збірник наукових прац̧ь Харківського національного університету Повітряних Сил. 2015. № 2. С. 3-8.

10. Фурашев В.М. Кіберпростір та інформаційний простір, кібербезпека та інформаційна безпека: сутність, визначення, відмінності. Інформація і право. № 2 (5). 2012. С. 162-175.

11. Шеломенцев В.П. Сутність організаційного забезпечення системи кібернетичної безпеки України та напрями його удосконалення. Боротьба з організованою злочинністю i корупщією (теорія і практика). Київ : Міжвідом. наук.-дослід. Центр з проблеми боротьби з організ. злочинністю. 2012. № 2 (28). С. 299-309.

КРАВЧУК М. Ю., кандидат юридичних наук, доцент кафедри кримінального права та процесу (Тернопільський начіональний економічний університет)

УДК 343.985:343.326

DOI https://doi.org/10.32842/2078-3736-2019-6-2-8

\title{
МІЖНАРОДНЕ СПІВРОБІТНИЦТВО УКРАЇНИ У СФЕРІ ПРОТИДЇ̈ ЗАГРОЗАМ БІОЛОГІЧНОГО ТЕРОРИЗМУ
}

У статті проаналізовано факт існування загроз біологічного тероризму як глобальну проблему світової спільноти та охарактеризовано тенденції міжнародної правової протидії цьому негативному явищу. Доведено, що протидія біотероризму вимагає консолідації зусиль усіх держав, а участь України у цьому процесі здійснюється відповідно до міжнародних договорів.

Здійснено аналіз норм окремих міжнародних нормативно-правових актів, що регулюють питання протидії тероризму. Визначено їх основні нормативно-правові приписи, необхідні для виконання Україною, які полягають у тому, що для ефективної боротьби зі збільшенням кількості і посиленням наслідків актів тероризму, а також у зв'язку із міжнародним характером терористичної діяльності, наша держава повинна посилювати співробітництво в цій сфері шляхом:

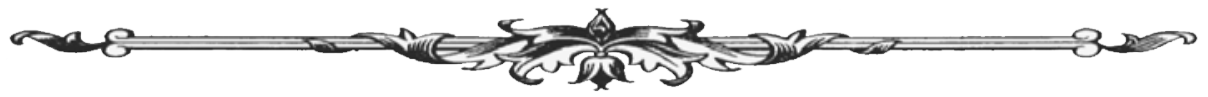


систематизації обміну інформацією про попередження тероризму; виконання міжнародних конвенцій; укладання угод про взаємну правову допомогу, а також забезпечення цілого ряду інших міжнародно-правових вимог. Визначено необхідним у найближчій перспективі законодавче закріплення плану адміністративних дій щодо протидії біотероризму та загрозам його виникнення, зокрема, удосконалення фізичного заходу об'єктів, на яких можуть здійснюватися біотерористичні акти, поліпшення планів координації дій на випадок надзвичайних ситуацій, що негативно впливають на санітарне та епідеміологічне благополуччя населення тощо. На підставі аналізу вітчизняного законодавства надані пропозиції щодо удосконалення окремих теоретико-прикладних засад міжнародного співробітництва України щодо протидії загрозам біотероризму. Зокрема, визначено нормативні підстави для правомірної відмови щодо виконання органами державної влади України запитів від іноземних держав, а також визначено необхідні напрями активізації та посилення обміну інформацією про біотерористичні загрози, суб'єктів їх вчинення, способи локалізації таких загроз тощо.

Як підсумок дослідження, визначено, що міжнародна антитерористична діяльність України пов'язана із діями щодо виконання приписів міжнародних документів, обміном точними та перевіреними даними відповідно до вимог внутрішнього законодавства про боротьбу з тероризмом, запропоновано напрями та способи зміни окремих норм національного законодавства для забезпечення більшої ефективності протидії біотерористичним загрозам у світі.

Ключові слова: біологічна загроза, запобігання тероризму, міждержсавне співробітництво, міжнародний документ, обмін інформаиією, резолюиї̈ Ради Європи $\mathrm{OOH}$.

The article analyzes the emergence of threats of biological terrorism as a global problem of the world community and describes the tendencies of international legal counteraction to this negative phenomenon. It is proved that counterterrorism requires consolidation of efforts of all states, and Ukraine's participation in this process is carried out in accordance with international treaties.

The norms of certain international normative legal acts regulating the issue of counter-terrorism are analyzed. Their main substantive regulatory content for Ukraine's implementation has been determined, which is that in order to effectively combat the increase and aggravation of the consequences of acts of terrorism, as well as in connection with the international nature of terrorist activity, our state must strengthen cooperation in this field by: systematizing the exchange of information on the prevention of terrorism; implementation of international conventions; concluding mutual legal assistance agreements, as well as providing a number of other international legal requirements. Legislative fixing of the administrative action plan for countering bioterrorism and threats of its occurrence, in particular, improvement of the physical activity of objects on which terrorist acts can be carried out, improvement of emergency coordination plans, negatively affecting sanitary and emergency management and sanitation, was determined necessary in the near future, well-being of the population, etc. On the basis of the analysis of the domestic legislation, the proposals on improvement of some theoretical and applied foundations of international cooperation of Ukraine on counteraction to the threats of bioterrorism are given, in particular, the normative grounds for the legitimate refusal to execute requests from foreign states by the state authorities of Ukraine are determined, as well as the necessary information on directions about bioterrorist threats, subjects of their perpetration, ways of localization of such threats, etc.

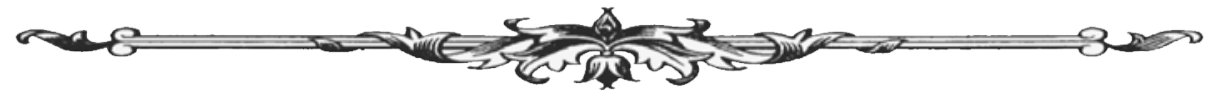


As a result of the research it is determined that the international anti-terrorist activity of Ukraine is connected with actions on the fulfillment of the prescriptions of international documents, exchange of accurate and verified data in accordance with the requirements of the domestic legislation on combating terrorism, directions and ways of change of certain norms of national legislation to provide greater effectiveness of counteraction bioterrorist threats in the world.

Key words: biological threat, prevention of terrorism, interstate cooperation, international document, exchange of information, resolutions of the Council of Europe.

Вступ. Серед сучасних світових негативних тенденцій тероризм посідає досить вагоме місце та становить глобальну проблему у світі. Саме тому світове співтовариство спрямовує значні зусилля на протидію цьому складному соціально-політичному явищу, що має різноманітні форми прояву. Як один із сучасних високотехнологічних видів тероризму, біологічний тероризм визнається міжнародним злочином, масштаби і ступінь поширення якого відповідають рівневі світової загрози. Протидія цій загрозі вимагає усе більшої консолідації різних держав, спільного використання досвіду, наявного у кожній країні, зокрема і в Україні. Адже у разі виникнення біотерористичних загроз Україна може брати участь у спільних антитерористичних заходах самостійно, а також шляхом сприяння іншим державам у подоланні на їх території зазначеної загрози.

Аналіз останніх досліджень і публікацій. Питання міжнародного співробітництва України у сфері боротьби з тероризмом як явищем реальної міждержавної суспільно-політичної негативної дійсності грунтовно досліджувалося представниками вітчизняної науки, такими як О.В. Губар, В.П. Смельянов, В.А. Коростиленко, В.В. Крутов, Д.Я. Кучма, Б.Д. Леонов, О.М. Литвак, В.А. Ліпкан, I.I. Мусієнко, Г.П. Синтик та іншими. Однак окреслена авторкою проблема місця і ролі України у міжнародному адміністративно-правовому регулюванні протидії загрозам біологічного тероризму є актуальною та такою, що спонукає науковців до формування елементів міжнародно-правового регулювання відносин протидії біотероризму.

Постановка завдання. Зазначене вище спонукало авторку до більш детального дослідження зазначеної проблематики та визначило мету нашої статті - на підставі аналізу міжнародних та вітчизняних нормативно-правових актів антитерористичного законодавства та окремих доктринальних положень сучасної правової науки дослідити окремі заходи міжнародного співробітництва України у сфері протидії загрозам біологічного тероризму та запропонувати шляхи удосконалення окремих норм вітчизняного антитерористичного законодавства для його максимального наближення та міжнародних вимог, а також 3 метою посилення рівня протистояння України можливим світовим біотерористичним загрозам.

Результати дослідження. Україна $є$ активним учасником протидії міжнародному (транснаціональному) тероризму, який, за авторським визначенням В.А. Ліпкана, є вчиненням терористичними злочинними групами та організаціями крізь державні кордони актів тероризму [1, с. 41]. Розширюючи теоретико-правове тлумачення вказаної категорії, звернімося до позиції О.М. Литвака, який визначає міжнародний тероризм як застосування державою (або групою, організацією) замаху на міжнародний правопорядок, насильством, спрямованим на досягнення міжнародно-протиправних цілей шляхом залякування осіб, що не $\epsilon$ безпосередньо жертвами нападів [2, с. 19].

Отже, міжнародне співробітництво України у боротьбі із загрозами виникнення біологічного тероризму як одного із сучасних високотехнологічних видів міжнародного тероризму здійснюється відповідно до міжнародних договорів та інших домовленостей про взаємну правову допомогу. Наша держава відповідно до укладених нею міжнародних договорів співпрацює в питаннях попередження, виявлення і припинення біотерористичних актів із різними суб' єктами, якими є іноземні держави, в особі їх правоохоронних органів та спеціальних служб, а також міжнародними організаціями, що здійснюють боротьбу з тероризмом.

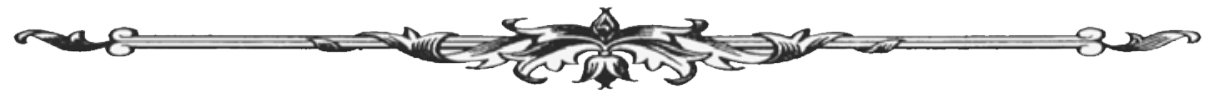


Здійснимо аналіз норм окремих міжнародних нормативно-правових актів, що регулюють питання протидії тероризму та діяльності України щодо їх виконання. Отже, у п. 6 Декларації ООН 60/43 від 8 грудня 2005 р. «Про заходи для ліквідації міжнародного тероризму» передбачено, що для ефективної боротьби зі збільшенням кількості і посиленням наслідків актів тероризму, а також у зв'язку із міжнародним характером терористичної діяльності, держави повинні посилювати співробітництво в цій сфері шляхом насамперед систематизації обміну інформацією про попередження тероризму і боротьбу з ним, а також ефективного здійснення відповідних міжнародних конвенцій й укладання угод про взаємну правову допомогу і видачу терористів на двосторонній, регіональній та багатосторонній основі [3].

Аналізуючи цю норму Декларації ООН відзначимо, що державам пропонується терміново переглянути сферу застосування наявних міжнародно-правових положень про попередження, припинення і ліквідацію тероризму в усіх його формах і проявах з метою забезпечення створення всеосяжних правових рамок, що включають усі аспекти цього питання.

На виконання зазначеної вище Декларації ООН Україна співпрацює з іншими країнами $з$ метою попередження, виявлення, припинення і розслідування терористичних актів, притягнення до відповідальності винних осіб і відшкодування збитків потерпілим державам i особам, а також у налагодженні взаємодії між правоохоронними органами і спеціальними службами іноземних держав та міжнародними організаціями, що здійснюють боротьбу з різними видами сучасних терористичних проявів.

Іншим важливим для виконання Україною $є$ Резолюція Ради Безпеки ООН №1456 від 20 січня 2003 р., відповідно до якої держави-учасники покликані: 1) невідкладно стати учасниками усіх відповідних міжнародних конвенцій і протоколів, що стосуються тероризму; 2) підтримувати всі міжнародні ініціативи, започатковані $з$ цією метою; 3) повною мірою використовувати джерела допомоги і майбутні рекомендації; 4) максимально сприяти у справі запобігання, розслідування та покарання за акти тероризму; 5) тісно взаємодіяти у питаннях здійснення у повному обсязі санкцій, спрямованих проти терористів та їх пособників; 6) вживати термінових заходів, щодо позбавлення терористів доступу до фінансових ресурсів, що необхідні для здійснення терористичної діяльності [4].

Необхідно підсумувати, що міжнародно-правове співробітництво України щодо протидії тероризму згідно з викладеною позицією Ради Безпеки ООН надасть результати лише за умови активізації зусиль на національному рівні щодо виконання норм міжнародного права, а також стійкого всеосяжного підходу, що включає активну участь і співробітництво всіх держав, міжнародних і регіональних антитерористичних організацій.

Окремим важливим елементом міждержавного співробітництва України визначається зазначеною вище Резолюцією Ради Безпеки ООН (попередньо було деталізовано у Міжнародній конвенції про боротьбу із фінансуванням тероризму 1999 року [5] та Резолюції Ради Безпеки ООН №1373 від 28 вересня 2001 р. [6]) пропозиція державам щодо «забезпечення залучення до судової відповідальності будь-якої особи, що бере участь у фінансуванні, плануванні, підготовці, здійсненні або підтримці терористичних актів» [4].

Прийняту Радою Європи Конвенцію про запобігання тероризму ратифіковану Законом України «Про ратифікацію Конвенції Ради Європи про запобігання тероризму» від 31 липня 2006 p. № 54-V. Україна, як і інші держави - члени Ради Європи, підписала цю Конвенцію 3 метою збільшення зусиль щодо запобігання тероризму і його негативним наслідкам, для більш повного забезпечення права людини на життя заходами національного рівня та шляхом міжнародного співробітництва.

Здійснений аналіз міжнародних нормативно-правових документів дає підстави авторці статті визначити необхідний для України у найближчій перспективі план закріплення у національному законодавстві адміністративно-правових дій щодо протидії біотероризму та загрозам його виникнення.

1. Вжити відповідних заходів, зокрема у сфері підготовки кадрів для правоохоронних та інших органів, з метою запобігання біотерористичній діяльності та ії негативним наслідкам з одночасним дотриманням зобов'язань стосовно прав людини. Крім того, необхідним

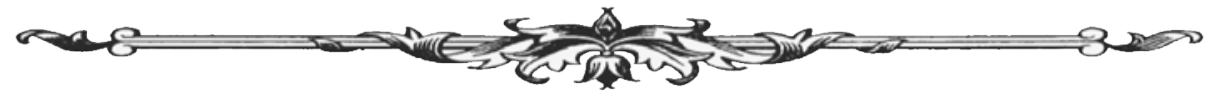


є вжиття таких заходів, які можуть бути корисними для поліпшення й розвитку співробітництва між національними органами з метою запобігання біотерористичним загрозам та їхнім негативним наслідкам шляхом: а) здійснення обміну інформацією; б) удосконалення фізичного заходу об'єктів, на яких можуть здійснюватися терористичні акти із застосуванням біологічної зброї та іï компонентів; в) поліпшення навчання й планів координації дій на випадок надзвичайних ситуацій, що негативно впливають на санітарне та епідеміологічне благополуччя населення.

2. Забезпечити здійснення просвітницьких заходів у сферах освіти, культури, інформації, засобів масової інформації з метою обізнаності населення стосовно існування, причин, серйозності біотерористичних загроз та наслідків їх вчинення. Адже, як зазначає О.Г. Братель, «біологічні засоби ураження через більш прості можливості їх виготовлення, а також їх токсичну властивість дозволяють здійснювати масові ураження за допомогою відносно невеликої кількості речовини, що використовується» [8, с. 79]. Роз' яснювальна робота щодо ймовірності наявних загроз біотерористичної діяльності повинна сприяти заохоченню громадськості до надання допомоги компетентним органам держави, що може сприяти запобіганню терористичним злочинам.

3. Залежно від обставин та з огляду на свої можливості Україна повинна надавати іншим країнам допомогу і підтримку з метою посилення здатності запобігати вчиненню біотерористичної діяльності, зокрема шляхом обміну інформацією, передовим досвідом протидії та здійснення інших можливих зусиль превентивного характеру.

Виходячи $з$ викладених вище вимог міжнародних документів щодо дій Україні у царині міжнародного співробітництва щодо протидії біотероризму, окремо необхідну звернути більш детальну увагу на такий аспект міжнародного співробітництва, як надання допомоги шляхом обміну інформацією про можливість існування біотерористичних загроз. Види такої допомоги визначаються Україною з огляду на міжнародні угоди, згода на обов'язковість яких надана ВР України і національним законодавством. Україна повинна надавати інформацію іншим державам 3 питань, пов'язаних із боротьбою з міжнародним тероризмом, на підставі відповідного запиту.

Однак, здійснивши аналіз норм Конституції України [9], Закону України «Про національну безпеку» [10] та ряду чинних нормативно-правових актів міждержавного співробітництва, ми встановли, що якщо інше не передбачено міжнародним договором, то у виконанні запитів іноземних держав відповідними органами державної влади України може бути відмовлено у наступних випадках: 1) запити спрямовані некомпетентним органом; 2) за своїм характером запити можуть завдати шкоди суверенітетові, безпеці або основним принципам правової політики нашої держави; 3) правопорушення, за яким подано запит, не розглядається як біотерористичний акт або злочин терористичної спрямованості; 4) запитувані або інші заходи, що спричинили аналогічні наслідки, не дозволені законодавством України або не стосуються правопорушення, з яким пов'язаний запит; 5) постанова про запитувані заходи не може бути винесена, або такі заходи не можуть бути виконані у зв'язку iз закінченням строку давності; 6) постанова, прохання про виконання якої направляється, не підлягає примусовому виконанню; 7) процедура, що передує прийняттю постанови, прохання про виконання якої направляється, не відповідає визнаним в Україні правам на захист; 8) є підстави вважати, що запитувані заходи, або постанова, про внесення якої подається запит, передбачають переслідування визначеної особи лише за расовою, статевою, релігійною, національною ознакою або через політичні переконання.

Досліджуючи міжнародні документи щодо протидії тероризму та нормативно-правові акти забезпечення національної безпеки, нами зроблена спроба визначити напрями першочергового національного нормативно-правового удосконалення заходів участі України у цьому процесі та визначити засоби уніфікації вітчизняного законодавства до основних засад до міжнародної антитерористичної політики. 3 огляду на це пропонується удосконалення системи адміністративно-правового забезпечення щодо підвищення рівня контролю за виробництвом, зберіганням та транспортуванням предметів, що можуть використову-

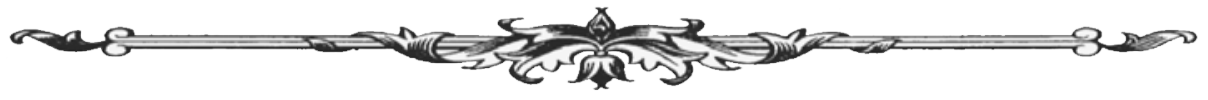


ватись як компоненти біологічної зброї для масового враження людей, тварин і рослин, а також спеціальних боєприпасів та бойових приборів із засобами доставки, що споряджені біологічними засобами.

Крім того, необхідним для ефективної участі України у процесі міжнародно-правової протидії біотерористичним загрозам $є$ різні види обміну інформацією про: 1) біотерористичні загрози: незаконні дослідження хвороботворних властивостей мікроорганізмів (бактерій, вірусів, грибків) та отрути, що виробляються деякими бактеріями, а також збудників значної кількості найбільш небезпечних хвороб людини - чуми, холери, сибірської виразки, сапу, висипного тифу, плямистої лихоманки тощо; 2) нові види біологічних речовин, що з'являються в незаконному обігу, технології їхнього виготовлення і використовуваних при цьому речовинах, а також про нові методи дослідження та ідентифікації таких речовин; 3) вчинені терористичні акти біологічного (бактеріологічного, хімічного) характеру або різного роду загрози учинення таких актів та причетних до них фізичних та/або юридичних осіб; 4) фізичних та юридичних осіб і об'єкти власності, що їх використовують для легалізації (відмивання) доходів від злочинної діяльності.

Серед інших заходів формування системи комплексної міжнародної протидії проявам біотероризму пропонується для України встановлення нормативно-правового забезпечення обміну проектами законодавчих та інших нормативно-правових актів, а також досвідом роботи, у тому числі проведення стажувань, консультацій, семінарів і навчальних курсів, а також інформацією про нові способи та засоби скоєння злочинів біотерористичного характеру та іншого впливу на санітарне та епідеміологічне благополуччя людини та інших видів живих організмів.

Висновки. На підставі викладеного вище можна зробити висновок, що Україна $\epsilon$ активним учасником міжнародної співпраці щодо запобігання терористичній діяльності у цілому та виявленню загроз біологічного тероризму зокрема. Така діяльність здійснюється нашою державою шляхом вжиття усіх практично можливих заходів. До таких заходів слід віднести зміни окремих аспектів національного законодавства для запобігання та протидії підготовки у межах власної території або за їі межами біотерористичних актів, в тому числі: 1) заходів, які забороняють на ії території незаконну діяльність осіб або організацій, які навмисно заохочують, підбурюють, організовують або вчиняють ці злочини; 2) заходів, що зобов'язують фінансові установи та інші організації, які беруть участь у здійсненні фінансових операцій, вживати заходів для ідентифікації постійних чи випадкових клієнтів, які здійснюють підозрілі операції, що можуть бути пов'язані із фінансуванням терористичної діяльності, чи заходів щодо ії підготовки. Крім того, міжнародна антитерористична діяльність України пов'язана із діями з обміну інформацією на міждержавному рівні, а також координацією заходів, які вживаються з метою попередження біотерористичних загроз шляхом створення та забезпечення функціонування каналів зв'язку між компетентними органами.

\section{Список використаних джерел:}

1. Ліпкан В.А. Тероризм і національна безпека України. Київ : Знання, 2000. 184 с.

2. Литвак О.М. Тероризм: соціально-психологічний аспект. Тероризм $i$ боротьба з ним: міжвідомчий науковий збірник. Під ред. А.І. Комарової та ін. Київ, 200. Т. 19(1). C. $202-205$.

3. Заходи з ліквідації міжнародного тероризму: Резолюція 60/43, прийнята Генеральною Асамблеєю Організації Об’єднаних Націй № 60/43 від 8 грудня 2005. URL: https://zakon. rada.gov.ua/laws/show/995 f87.

4. Резолюція 1456 (2003), ухвалена Радою Безпеки на іiі 4688-му засіданні, 20 січня 2003. URL: https://zakon.rada.gov.ua/laws/main/995_b22.

5. Міжнародна конвенція про боротьбу із фінансуванням тероризму. Документ ООН A/54/615 від 1999 p. URL: https://zakon.rada.gov.ua/ laws/main / 995_518.

6. Резолюція 1373 (2001), ухвалена Радою Безпеки на їі 4385-му засіданні, 28 вересня 2001 року. URL. : https://zakon.rada.gov.ua/laws/main/995_854?lang.

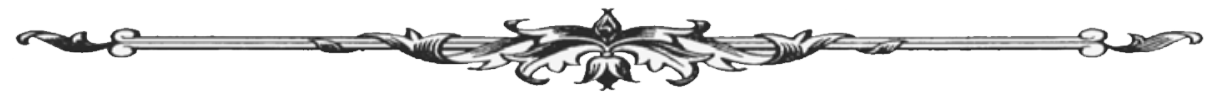


7. Про ратифікацію Конвенції Ради Європи про запобігання тероризму: Закон України від 31 липня 2006 року № 54-V. Відомості Верховної Ради Украӥни. 2006, N 39, ст. 340.

8. Братель О.Г. Екологічний терроризм як дестабілізуючий фактор національної безпеки України. Териризм і національна безпека України: Матеріали міжнар. конф. Київ : Нац. акад. внутр. справ України, 2002. С. 77-84.

9. Конституція України: Закон від 28.06.1996. № 254к/96-BP. URL : http://zakon5.rada. gov.ua.

10.Про національну безпеку: Закон України від 21.06.2018. № 2469-VIII. Вiдомості Верховної Ради, 2018, № 31, ст. 241.

ПРИХОДЬКО А. А.,

кандидат юридичних наук, адвокат

УДК 342.951:351.82

DOI https://doi.org/10.32842/2078-3736-2019-6-2-9

\section{КОРУПЦІЙНИЙ ЧИННИК ЯК ДИСТАБІЛІЗАЦІЙНИЙ ЕЛЕМЕНТ НА ШЛЯХУ ДО ЄВРОІНТЕГРАЦІї}

Стаття присвячена аналізу результативності сформованої антикорупційної політики України та дослідженню реального стану виконання низки вимог Європейського Союзу, висунутих Україні в рамках Угоди про асоціацію між Україною, з однієї сторони, та Європейським Союзом, Свропейським співтовариством 3 атомної енергії і їхніми державами-членами, 3 іншої сторони, де перша взяла на себе зобов'язання з вирішення проблем у досліджуваній сфері. Автором розглянуто корупцію як явище, що перешкоджає становленню України повноцінним членом Європейського Союзу, досліджено статистичну й аналітичну інформацію щодо масштабів корупції в Україні на основі офіційних документів основних міжнародних партнерів України. Автором оцінено сучасний стан запобігання та протидії корупції в Україні як задовільний, обумовлюючи таку позицію відсутністю стратегічного планування, зокрема затвердженої антикорупційної стратегії на 2018-2020 роки. Зазначено, що активізація викорінення системної корупції почалась тільки зараз, наприкінці 2019 року. Незважаючи на те, що Угода про асоціацію між Україною, з однієї сторони, та Свропейським Союзом, Свропейським співтовариством з атомної енергії і їхніми державами-членами, 3 іншої сторони, офіційно набула чинності 1 вересня 2017 року. Загалом, автор дійшов висновку, що вимоги Європейського Союзу до України, висунуті в рамках зазначеної Угоди, у досліджуваній сфері загалом реалізуються, однак якість таких дій є дещо сумнівною. Вбачається, що доки українська спільнота буде пасивно реагувати на корупційні прояви, уповноважені суб'єкти будуть діяти в рамках обмежених спроможностей та в умовах, що не відповідають стандартам європейського законодавства, - чекати позитивних зрушень марно.

Ключові слова: антикорупиійна політика, антикорупиійна стратегія, ВАС, євроінтеграція, СС, корупиійні прояви, корупчія, НАБУ, НАЗК, протидія та запобігання корупиї, публічна адміністрація.

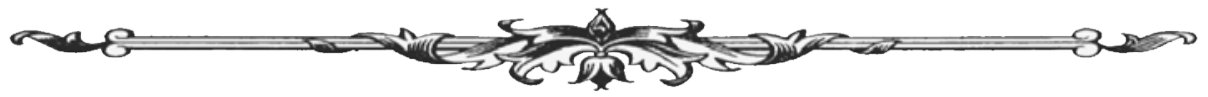

